\title{
Conceptions about mathematics, its teaching and learning in \\ Compendio Mathematico (1707) written by the Spanish Thomas \\ Vicente Tosca (1651-1723)
}

\author{
Concepções sobre as matemáticas, seu ensino e sua aprendizagem no \\ Compendio Mathematico (1707) escrito pelo espanhol Thomas Vicente Tosca
}

(1651-1723)

\author{
Antonio M. Oller-Marcén* \\ ORCID iD 0000-0002-8191-3199 \\ José M. Muñoz-Escolano** \\ ORCID iD 0000-0002-8713-4591
}

\begin{abstract}
The preface of a book is one of the main examples of paratexts, defined by Gérard Genette as those devices and conventions that enable a text to become a book. It can provide information about aspects such as the author's motivation and intention, the origin of the presented ideas, the potential readers, etc. In the particular case of a mathematical text devoted to some extent to teaching, the preface can provide information about the author's conceptions and beliefs about mathematics, its teaching and learning. In this work, we analyze the preface of Compendio Mathematico written by Thomas Vicente Tosca in 1707. This approach will allow us to have a view of how the teaching and learning of mathematics as well as mathematics itself were conceived during Spanish preenlightenment.
\end{abstract}

Keywords: Conception. Belief. Mathematics. 18th century. Spain.

\section{Resumo}

O prólogo de um livro é um dos múltiplos exemplos de paratextos, definidos por Gérard Genette como esses elementos e convenções que fazem um texto tornar-se um livro. Isso pode fornecer informações sobre aspectos como a motivação e a intenção do autor, a origem das ideias apresentadas, potenciais leitores etc. No caso particular de textos matemáticos dedicados em certa medida ao ensino, o prólogo pode informar as concepções e crenças do autor sobre a matemática, seu ensino e sua aprendizagem. Neste trabalho, analisamos o prólogo do Compendio Mathematico, escrito por Thomas Vicente Tosca em 1707. Essa abordagem nos permitirá obter uma visão sobre como a matemática, seu ensino e sua aprendizagem foi concebida durante a pré-ilustração na Espanha.

Palavras-chave: Concepção. Crença. Matemáticas. Século XVIII. Espanha.

\footnotetext{
* $\mathrm{PhD}$ from the University of Valladolid (UVA). Associate professor at the Defence University Center at Zaragoza (CUDZ), Zaragoza, España. Address for correspondence: Ctra. de Huesca s/n, Zaragoza, España; CP: 50090. Email: oller@unizar.es.

${ }^{* *} \mathrm{PhD}$ on Mathematics from the University of Zaragoza (UZ). Associate professor at the University of Zaragoza (UZ), Zaragoza, España. Address for correspondence: C/ Pedro Cerbuna 12, Zaragoza, España; CP 50009. E-mail: jmescola@unizar.es.
} 


\section{Introduction and Objective}

Thomas Vicente Tosca was born and lived in the city of Valencia between 1651 and 1723. He was quite a multifaceted person who was not only interested in mathematics, philosophy or theology, but also in more practical disciplines such architecture or cartography (ROSELLÓ, 2004).

He initiated, together with fellow mathematicians Baltasar de Iñigo and Juan Bautista Corachán, the novator center in Valencia (NAVARRO, 2007). This movement, dating back to the end of the $17^{\text {th }}$ century, tried to set the foundations for the renewal of Spanish mathematics. In particular, this Valencian branch of the novator movement was oriented towards the creation of a mathematics academy. This academy dealt, among other aspects, with the nature and applications of mathematics. In fact, the first meeting was on the topic "method, certainty and usefulness of mathematics" (DORCE, 2017).
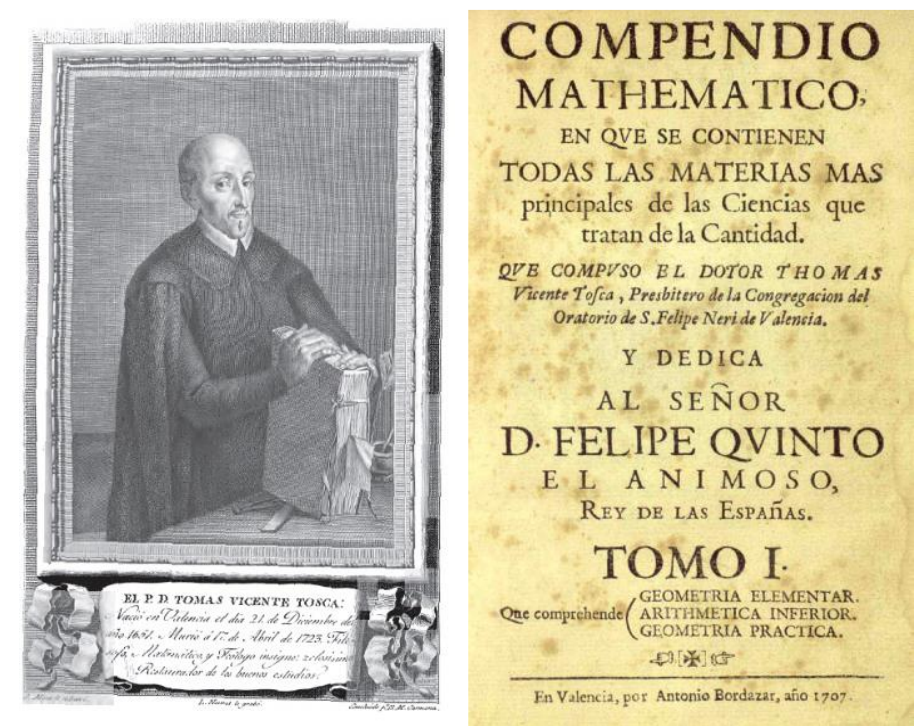

Figura 1 - Portrait of Thomas Vicente Tosca (left) and cover page the first edition of his Compendio Mathematico (right)

Source: Spanish National Library

In addition to this interest on what we could call foundations of mathematics, Tosca himself had a clear interest in mathematics teaching. Even if he did never teach at the university level, he maintained a mathematics school for more than 20 years in two different periods of his live. For an account on the life and scientific personality of Tosca, we refer the reader to the work of Navarro (1987).

Tosca is mostly known for two of his works: Compendio Mathematico and Compendium Philosophicum. Compendio Mathematico was published between 1707 and 1715. This work had a clear encyclopedic character and it was inspired (CAPEL, 1982; DORCE, 2017) by the 
Cursus seu mundus mathematicus written by the French Jesuit Claude François Milliet Dechales. The publication of the first volume in 1707 was "an important event" (NAVARRO, 1987, p. 8) and its influence and importance is clear if we observe that new editions appeared in 1727, 1757 and 1760. Furthermore (NAVARRO LOIDI, 2013, p. 70), this book was used as a textbook in the Royal Academy of Midshipmen at Cádiz and it is very likely that is was used in other military academies and teaching institutions at that time. For instance, Massa-Esteve, Roca-Rosell and Puig-Pla (2011) point out Tosca's work as one of the main basis of Pedro Lucuce's Curso Mathematico para la Instrucción de los Militares. Tosca also influenced, among others, the Portuguese Teodoro de Almeida (RODRÍGUEZ PARDO, 2008, p. 232). His main work, the Recreação Filosófica (DOMINGUES, 1988), as well as the Cartas FísicoMatemáticas which completed it (OLLER MARCÉN; MEAVILLA SEGUÍ, 2013) seem to pursue a similar goal to that of Tosca's works.

Compendio Mathematico consists of 28 treatises distributed among nine volumes which titles, providing a clear information about their content, can be found in Table 1.

\begin{tabular}{|c|c|}
\hline Volume & Content \\
\hline I & Elementary geometry, lower arithmetic and practical geometry \\
\hline II & Higher arithmetic, algebra, music \\
\hline III & Trigonometry, conic sections, machinery \\
\hline IV & Statics, hydrostatics, hydrotechnics, hydrometrics \\
\hline V & Civil architecture, stonework, military architecture, pyrotechnics, artillery \\
\hline VI & Optics, perspective, catoptrics, dioptrics, meteors \\
\hline VII & Astronomy \\
\hline VIII & Practical astronomy, geography, navigation \\
\hline IX & Gnomonics, ordination of time, astrology \\
\hline
\end{tabular}

Table 1 - Content of Tosca's Compendio Mathematico

Source: Prepared by the authors

In (MARCO, 1965a, 1965b, 1965c) a somewhat detailed content description of Tosca's work is given. More recently Dorce (2017) also provides an account of the content for each of the nine volumes of Compendio. Navarro (1978) provides a detailed comparison between Tosca's work and that of the most representative contemporary authors. As Massa-Esteve, Roca-Rosell and Puig-Pla (2011, p. 5) point out, Tosca's work covers both pure and mixed mathematics (as classified at that time) even if he seems to prefer a classification between pure and physico-mathematics. It is also noteworthy (DORCE, 2007) that the Compendio does not include any reference to analytic geometry or to infinitesimal calculus.

In addition, the first volume includes a "Brief introduction to mathematical disciplines" which, in some sense, serves as a preface to the whole text. In this introduction, Tosca writes about topics such as "parts in which mathematics is divided" (pp. 3-5) or "the method to teach and learn mathematics" (pp. 7-8). Hence, this introduction can help us have a closer view of 
Tosca's ideas on mathematics as a science but also on mathematics as a topic to be taught and learned.

Accordingly, the main objective of this work is to identify conceptions and beliefs of Thomas Vicente Tosca about mathematics, its teaching and learning. In particular, we are interested in tracing them in the preface of Compendio Mathematico. In order to achieve our main objective, we will focus on two sub-goals: first, identify the topics, themes or categories about which Tosca provides information in his work and, second, obtain and analyze the information contained in this preface.

\section{Theoretical framework}

Even though textbooks might be inherent to the act of teaching (MUNAKATA, 2016), the concept of a textbook is difficult to define and varies throughout history. According to Pationitis (2006, p. 801), a textbook is "a book containing a systematic presentation of a subject principles, or a collection of writings dealing with a specific subject" which primary purpose is "to be used in education or as a reference work". Lorentz and Vechia (2004) point out the interest and usefulness of analysing historical textbooks. Moreover, Schubring (1987, p. 41) states that "investigating the personality of a schoolbook author [...] can enable us to get insight into the social meaning of school knowledge". An interesting review of different approaches to textbook analysis can be found in (ANGULO; RUBIO, 2016).

Swetz (1995) claims that historical mathematics texts not only tell us about mathematical concepts, but also about pedagogical issues such as content organization or teaching methods and techniques. An interesting example of this fact is the work of BarrowGreen (2010) in which the role of Euler as an educator is analysed. In addition, Maz and Rico (2015) show that textbooks can also transmit ideas that are, in some sense, alien to the subject, such as values, political or social positions, etc. Ancient textbooks can also provide information about the daily life activities that took place at the time they were written (MADRID; MAZMACHADO; LEÓN-MANTERO; LÓPEZ-ESTEBAN, 2017).

Consequently, mathematics textbooks, even if this science is usually seen as abstract and impersonal, can contain not only scientific facts (definitions, propositions, rules, examples, etc.) but also information about the author's conceptions and beliefs. In this respect, Saxon (2011) investigates the different pedagogical techniques present in Decartes' Géométrie drawing conclusions about Descartes' pedagogical beliefs.

In the mathematics education field, there are several works analysing the conceptions 
and beliefs of the different actors involved in teaching and learning processes (students, inservice primary and secondary teachers, prospective teachers, etc.) regarding different aspects of mathematics, its teaching and its learning (LEDER; PEHKONEN; TÖRNER, 2002; THOMPSON, 1992; PAJARES, 1992; PONTE, 1994). Establishing a precise definition of the terms 'conception' and 'belief' is controversial (GOLDIN; RÖSKEN; TÖRNER, 2009). In this work, we will follow the approach of Flores (1998) which is strongly based on previous work by Ernest (1991).

Flores, Batanero and Godino (2000) design tools in order to study the changes of conceptions and beliefs on mathematics among Secondary School prospective teachers. They analyse students' texts elaborated before and after their internship period in high school. To perform the analysis, they consider five planes in order to classify conceptions and beliefs: epistemological, cognitive-epistemological, didactical, cognitive-didactical, and didacticepistemological. They also consider another variable that describes the interactions between the subject and the knowledge, which can be: gnosiological, ontological, and validative. Even though the previous research is quantitative and inferential, the tool can be adapted to analyse ancient mathematical texts from a qualitative and descriptive point of view.

In order to identify conceptions and beliefs of a textbook author, we can have a look at the so-called paratexts. Genette (1997) defines paratexts as those devices and conventions that "enable a text to become a book" (p. 1). Some examples of paratexts are the title, the figures, the footnotes, the table of contents, etc. The analysis of paratexts can provide interesting information. For example, Garnica, Gomes and Andrade (2012), in their detailed study of Lacroix's Essais sur l'enseignement en général, et sur celui des mathématiques en particulier, focus, among other aspects, on paratexts.

A very important and ancient example of paratext is given by the preface, or author's introduction (VITRAC, 2008). According to Gennete (1997, p. 197), the main function of a preface is "to ensure that the text is read properly". This implies that a preface contains information about how and why read the book. Regarding the why, the preface can contain considerations about the importance, novelty, or veracity of the text. Regarding the how, it can contain considerations about the genesis of ideas, the potential readers, the intentionality, the order in which the book must be read, etc.

In the case of a mathematics textbook, the preface can provide interesting information regarding the author's position with respect to different aspects of mathematics and its teaching and learning. Vitrac (2008) presents a detailed analysis of prefaces in ancient Greek Mathematical texts. Although it was not the preface to his own text, Rampling (2011) analyzes 
John Dee's 'Mathematicall praeface' to Euclid's Elements. Christiansen (2015) shows the contextual and didactical information that can be found in prefaces examining a Norwegian 19th century arithmetic textbook.

\section{Method}

We carry out a case study with a mostly qualitative character. Moreover, our approach is exploratory and descriptive. We use documents as the main source of information and we focus on the content (PRIOR, 2016). The quality criteria pointed out by Scott (1990) for this kind of research (authenticity, credibility, representability and meaning) are clearly achieved in this study because we are analysing the original text.

In order to identify the topics, themes or categories about which Tosca provides information in his work, we follow a deductive approach for which we developed a system of nine categories which description can be found in Table 2. They have been adapted from previous work by Flores (1998).

The Table 2 rows correspond in some sense to the vertices of the so-called pedagogical triangle (HOUSSAYE, 1988), which are the knowledge (mathematics in our case), the teacher and the students. On the other hand, the three columns correspond to the distinction of Ernest (1991) between ontology (involving those aspects regarding the nature of the considered knowledge) and gnosiology (involving those aspects regarding how the considered knowledge is acquired) in the context of mathematics epistemology. Nevertheless, even if Ernest considers validation or validity aspects as a part of gnosiology, we have opted to consider them as an independent category. In the mathematics plane, validity aspects are related to the degree of truth or reality that is assigned to mathematical objects and results. In the teaching and learning planes, validation aspects are involved on the evaluation and assessment of teaching and learning processes.

\begin{tabular}{|l|c|c|c|}
\hline $\begin{array}{c}\text { Mathematics } \\
\text { plane }\end{array}$ & Ontology & Gnosiology & Validation/validity \\
\hline Teaching plane & $\begin{array}{c}\text { What is it useful for? } \\
\text { teach mathematics? }\end{array}$ & $\begin{array}{c}\text { How is mathematics } \\
\text { made or discovered? }\end{array}$ & $\begin{array}{c}\text { How is mathematical knowledge } \\
\text { sanctioned? }\end{array}$ \\
\hline Learning plane & $\begin{array}{c}\text { What does it mean to } \\
\text { learn mathematics? }\end{array}$ & $\begin{array}{c}\text { How can or must we } \\
\text { learn mathematics? }\end{array}$ & $\begin{array}{c}\text { How do we validate the teaching } \\
\text { of mathematics? }\end{array}$ \\
\hline
\end{tabular}

Table 2 - Categories for the thematic analysis

Source: Prepared by the authors

To identify the categories described in Table 2 (first sub-goal), we use elements of thematic analysis (BRAUN; CLARKE, 2006). On the other hand, the main research method 
used for obtaining and analysing the information contained in the preface (second sub-goal) is content analysis (KRIPPENDORF, 2014). The units of analysis were the sentences of Tosca's preface and the text was transcribed and codified using the software QDA Miner 4 Lite.

\section{Results}

As we pointed out, Tosca's work begins with a preface consisting of ten pages. We begin by giving a description of all its content. After a brief introduction in which Tosca praises the importance, the usefulness and the worthiness of Mathematics, the preface is organized in six sections (see Table 3).

\begin{tabular}{|c|c|}
\hline Section 1 & Object, nature and division of mathematics \\
\hline Section 2 & Parts in which mathematics is divided \\
\hline Section 3 & Origin, advance and usefulness of Mathematics \\
\hline Section 4 & Method for Mathematics teaching and learning \\
\hline Section 5 & Explanation of some frequent terms in Mathematics \\
\hline Section 6 & Explanation of the most frequent citations \\
\hline
\end{tabular}

Table 3 - Contents of Tosca's preface

Source: Prepared by the authors

In Section 1, Tosca states that "the object of mathematics is quantity". In addition, he divides Mathematics into "pure" and "non-pure" (that he calls "physico-mathematical sciences") depending on the role played by "the senses". Thus, pure Mathematics (Arithmetic or Geometry for instance) consider quantity independently of the senses while non-pure Mathematics (Music or Optics, for instance) take into account sensitive properties.

Section 2 is devoted to refining the previous classification. Tosca considers that purely mathematical sciences are: Geometry, Arithmetic, Algebra, Trigonometry and Logarithmic. On the other hand, physico-mathematical sciences are: Music, Mechanics, Statics, Hydrostatics, Civil Architecture, Military Architecture, Artillery, Optics, Geography, Astronomy and Cosmography. For each of these disciplines, he also provides a brief explanation of its object.

In Section 3, Tosca traces the origin of mathematics back to God himself. Giving a long list of ancient Greek mathematicians and explicity mentioning the jesuit Milliet Dechales. He also mentions a list of kings and saints also related to Mathematics. Finally, Tosca talks about the general usefulness of Mathematics giving some examples in the context of some particular disciplines such as Optics or even Theology.

Section 4 deals with the method by which Mathematics should be taught and learnt. Tosca pays great attention to the order under which the disciplines described in Section 2 must be introduced to the students. 
Finally, Section 5 and 6 explain some specialized mathematical terminology (definition, axiom, theorem, corollary, etc.), describe the formal structure of the text (treatises, books, etc.), and establish a notation system for referencing the different text results.

In Table 4, we can see which of the nine previously defined categories (recall Table 2) were covered in Tosca's preface.

\begin{tabular}{|c|c|c|c|}
\hline & Ontology & Gnosiology & Validation/validity \\
\hline Mathematics plane & Yes & Yes & Yes \\
\hline Teaching plane & No & Yes & No \\
\hline Learning plane & No & Yes & No \\
\hline
\end{tabular}

Table 4 - Categories identified in Tosca's preface

Source: Prepared by the authors

We observe that Tosca pays special attention to the mathematics plane. In addition, the teaching and learning planes are only mentioned at a practical level (how to teach or how to learn) with no comments about the nature of these activities or about any kind of validation for them. Now, for each of the five categories that were found in the analysed preface, we are going to present some examples that we think illustrate Tosca's thought.

The mathematics plane is the only one that was covered by Tosca from the three considered points of view (ontological, gnosiological, and validative). The ontological point of view is mainly covered in the introduction and in Sections 1,2 and 3. Tosca defines quantity as the object of Mathematics, he classifies its disciplines into pure and non-pure and he points out its usefulness and its applications to other sciences. Some examples of interesting statement about this point of view are:

- "The object of mathematics is quantity [...] it is about finding and proving the properties and attributes of quantities".

- "I divide them between pure and non-pure".

- "In addition to its nobility, it is very useful".

- "They make you apt to better learn other sciences".

The gnosiological point of view is scattered throughout the text, mostly appearing in the introduction and Sections 3 and 5, where the author describes the historical evolution and terminology of Mathematics. Doing Mathematics requires effort, it implies the use of a specific specialized terminology and it is based upon the prior work of other authors. Some examples of statements about this topic are:

- "Nor the time spent in its study will be wasted; neither the sweat will be in vain".

- "Mathematics has greatly advanced by mean of many and distinguished authors".

- "Authors, both ancient and modern, use the following terms in their mathematical 
treatises: definitions, axioms, postulates, [...]".

Finally, regarding the validation or validity point of view, it is covered both in the introduction and in Section 3. For Tosca, the truth in Mathematics arises both from its divine origin and from the logical nature of its discourse. Some examples of sentences dealing with this point of view are:

- "It lacks the doubts and opinions that are common to other sciences".

- "God transmitted to our first father Adam the idea of mathematics".

- "The cleanliness of its truths, the energy of its proofs, the clarity of its demonstrations and the continuous string of its consequences".

Now, Tosca only covered the teaching plane in his preface from the gnosiological point of view in Section 4. For Tosca, the order in which topics are presented is essential in the teaching of Mathematics. The logical relationship between them must be taken into account as well as their difficulty. A few examples of sentences on this topic are:

- "All the material must we arranged in an order such that the different topics arise one from the other".

- "If possible, mix the hard with the delectable".

Accordingly, the learning plane was also covered only from the gnosiological point of view in the same section. The main idea is that the student must strictly adhere to the plan designed by his teacher provided it follows the above ideas. Let us present some exemplifying sentences on this regard:

- "The student will happily end his enterprise if he follows the aforementioned order".

- "Those who, not having understood the first treatises, would try to study the following ones, would be wasting their time and effort”.

\section{Discussion and conclusions}

The analysis of the preface to Tosca's Compendio Mathematico provides an interesting view of the author's beliefs and conceptions about different aspects of mathematics, its teaching and learning. Some of the ideas present in the text can be traced back to previous influencial authors in Spain, like Juan Pérez de Moya (MUÑOZ-ESCOLANO; OLLER-MARCÉN, 2018). Moreover, taking into account the great importance of Tosca's work (DORCE, 2017) it is quite likely that his ideas had a deep impact over the $18^{\text {th }}$ century Spanish mathematics.

Regarding mathematics, Tosca focuses mainly on concepts (mathematics as the science 
of quantity) rather than on the thought processes that are involved. The validity of mathematical knowledge has a certain divine origin and mathematical truths are doubtless as far as they are founded on clear and logically consistent proofs. These facts point out that Tosca had a platonic view of mathematics, according to the description of Ernest (1991, pp. 29-30).

As it was common during the $18^{\text {th }}$ century (MASSA-ESTEVE; ROCA-ROSELL; PUIG-PLA, 2011), Tosca makes a clear distinction between what we would call today pure and applied mathematics, but he makes a clear stress on practical applications introducing natural philosophy under the explicit mention of physico-mathematical disciplines. This stress coincides, for instance, with information contained in Dee's praeface (RAMPLING, 2011). In addition, it is interesting to observe that the formative value of mathematics is also stated in the analysed text, just like in Euler's work, when he claims (BARROW-GREEN, 2010) that learning arithmetic is a good way for teaching correct thinking. For Tosca, the work of a mathematician implies great intellectual effort (sweat is mentioned). Moreover, in spite of his platonic view, he considers that mathematical knowledge has been built in a cumulative way thanks to the work of previous generations.

Tosca seems to think that the systematicity in the presentation of mathematical work is very important. Accordingly, the role of the teacher essentially consists in adequately arranging the material for their students. The order in which contents are presented as well as their difficulty are considered in absolute terms (showing again a certain platonism) and then it is the teacher's duty to discover some optimal order as well as to determine which are the delectable and the hard contents. This latter idea is also present in Descartes' work (DEAN, 2011).

For Tosca, in the light of the preface order described in Section 4, it seems that delectable and hard can be cosidered as synonyms of pure and non-pure mathematics. For example, elementary Geometry and Arithmetic are followed by practical Geometry. Then higher Arithmetic and Algebra are introduced followed by Music. Regarding teaching aspects, it is also noteworthy, as Dorce $(2017$, p. 36$)$ points out, that, in many situations, Tosca provides particular examples of general results. Tosca also chose some of his sources motivated by their simplicity for the students (DORCE, 2017).

Finally, turning to learning aspects, Tosca's ideas are a clear consequence of his considerations about teaching. In this context, the main role of an apprentice is to adhere to the teacher's decisions because, otherwise, he would be wasting his time and effort. This observation is of no little importante if we take into account that during $18^{\text {th }}$ century, the “didactical and pedagogical century by excellence" (LLOPIS; CARRASCO, 1983, p. 17), a working knowledge of mathematics became increasingly more a requirement not only for 
public servants or military men like it had been in the previous centuries, but also for craftsmen and, progressively, for all social levels.

\section{Acknowledgements}

This work has been partially funded by the Spanish Ministry of Economy and Competitiveness (Project EDU2016-78764-P) and by the Government of Aragon and the European Social Fund (Group S36_17D).

\section{References}

ANGULO, K. M.; RUBIO, A. M. B. Los contextos de transmisión y recepción de los manuales escolares: una vía de perfeccionamiento metodológico en manualística. História da Educação, Porto Alegre, v. 20, n. 50, p. 29 - 48, sept./dec. 2016.

BARROW-GREEN, J. Euler as an educator. BSHM Bulletin: Journal for the British Society for the History of Mathematics, London, v. 25, n. 1, p. 10 - 22, 2010.

BRAUN, V.; CLARKE, V. Using thematic analysis in psychology. Qualitative Research in Psychology, Philadelphia, v. 3, n. 2, p. 77 - 101, 2006.

CAPEL, H. Geografía y matemáticas en la España del siglo XVIII. Barcelona: oikos-tau, 1982. $341 \mathrm{p}$.

CHRISTIANSEN, A. The function of a preface: Contextual information and didactical foundation described in the preface of a textbook in arithmetics from 1825. In: BJARNADÓTTI, K. et al. (Ed.). "Dig where you stand" 4. Proceedings of the fourth International Conference on the History of Mathematics Education, Torino: Edizioni Nuova Cultura, 2017. p. 415 - 416.

DEAN, A. S. An investigation of pedagogical techniques in Descartes' La Géométrie. BSHM Bulletin: Journal for the British Society for the History of Mathematics, London, v. 26, n. 3, p. 167 $177,2011$.

DOMINGUES, F. C. Um projecto enciclopédico y pedagógico: a 'Recreação Filosófica' de Teodoro de Almeida. Revista de História das Ideias, Coimbra, v. 10, p. 235 - 248, 1988.

DORCE, C. Les lleis de Kepler en un tractat astronòmic espayol del segle XVIII: el Compendio Mathematico de Tomàs Vicenç Tosca (1715). Actes d'història de la ciència i de la técnica, Barcelona, v. 2, n. 1, p. 113 - 125, 2007.

DORCE, C. Historia de las matemáticas en España. II - De los novatores al siglo XX. Sant Cugat: Arpegio, 2017. $433 \mathrm{p}$.

ERNEST, P. The philosophy of mathematics education. London: Falmer Press, 1991. 329 p.

FLORES, P. Concepciones y creencias de los futuros profesores sobre las matemáticas, su enseñanza y aprendizaje. Investigación durante las prácticas de enseñanza. Granada: Comares, 1998. $280 \mathrm{p}$. 
FLORES, P.; BATANERO, C.; GODINO, J. D. Aplicación del análisis de textos mediante técnicas multivariantes al estudio del cambio de concepciones sobre las matemáticas, su enseñanza y aprendizaje. Revista latinoamericana de investigación en matemática educativa, México D.F., v. 3, n. 3 , p. 339 - 356, nov. 2000.

GARNICA, A. V. M.; GOMES, M. L. M.; ANDRADE, M. M. The Memoirs of Lacroix: on public education in revolutionary France, in general, and on the teaching of mathematics, in particular. Bolema: Boletim de Educação Matemática, Rio Claro, v. 26, n. 44, p. 1227 - 1260, dec. 2012.

GENETTE, G. Paratexts: thresholds of interpretation. Cambridge: Cambridge University Press, 1997. $456 \mathrm{p}$.

GOLDIN, G.; RÖSKER, B.; TÖRNER, G. Beliefs - No Longer a Hidden Variable in Mathematical Teaching and Learning Processes. In MAAß, J.; SCHÖGLMANN, W. (Ed.). Beliefs and Attitudes in Mathematics Education. New Research Results. Rotterdam: Sense publishers, 2009. p. 1 - 18.

HOUSSAYE, J. Le triangle pédagogique. Berna: Peter Lang, 1988. 300 p.

KRIPPENDORFF, K. Content analysis. An introduction to its methodology. London: SAGE, 2014. $456 \mathrm{p}$.

LEDER, G.; PEHKONEN, E.; TÖRNER, G. Beliefs: A Hidden Variable in Mathematics Education? Holland: Kluwer Academic Publishers, 2002. 388 p.

LLOPIS, J.; CARRASCO, M. V. Ilustración y educación en la España del siglo XVIII. Valencia: Escuela universitaria de Formación de Profesorado de E.G.B., 1983. 240 p.

LORENTZ, K.M.; VECHIA, A. Os livros didáticos de matemática na escola secundária brasileira no século XIX. História da Educação, Porto Alegre, v. 8, n. 15, p. 53 - 72, jan./jun. 2016.

MADRID, M. J. et al. Aplicaciones de las Matemáticas a la Vida Diaria en los Libros de Aritmética Españoles del Siglo XVI. Bolema: Boletim de Educação Matemática, Rio Claro, v. 31, n. 59, p. 1082 - 1100, dec. 2017.

MARCO, R. El "Compendio Mathematico" del Padre Tosca y la introducción de la ciencia moderna en España I. Las matemáticas. In: CONGRESO ESPAÑOL DE HISTORIA DE LA MEDICINA, 2. 1965. Salamanca. Actas ... Salamanca: Sociedad Española de Historia de la Medicina, 1965a. p. 325 332.

MARCO, R. El "Compendio Mathematico" del Padre Tosca y la introducción de la ciencia moderna en España II. La astronomía. In: CONGRESO ESPAÑOL DE HISTORIA DE LA MEDICINA, 2. 1965. Salamanca. Actas ... Salamanca: Sociedad Española de Historia de la Medicina, 1965b. p. 333 344.

MARCO, R. El "Compendio Mathematico" del Padre Tosca y la introducción de la ciencia moderna en España III. La física. In: CONGRESO ESPAÑOL DE HISTORIA DE LA MEDICINA, 2. 1965. Salamanca. Actas ... Salamanca: Sociedad Española de Historia de la Medicina, 1965c. p. 345 - 357.

MASSA-ESTEVE, M. R.; ROCA-ROSELL, A.; PUIG-PLA, C. "Mixed" Mathematics in Engineering Education in Spain. Pedro Lucuce's course at the Royal Military Academy of Mathematics of Barcelona in the Eighteenth century. Engineering Studies, London, v. 3, n. 3, p. 233 - 253, dec. 2011.

MAZ, A.; RICO, L. Principios didácticos en textos españoles de matemáticas en los siglos XVIII y XIX. Revista Latinoamericana de Investigación en Matemática Educativa, México D.F., v. 18, n. 1, p. 49 - 76, mar. 2015 
MUNAKATA, K. Livro didático como indício da cultura escolar. História da Educação, Porto Alegre, v. 20, n. 50, p. 119 - 138, sept./dec. 2016.

MUÑOZ-ESCOLANO, J. M.; OLLER-MARCÉN, A. M. Análisis de los prólogos de los textos matemáticos del Bachiller Juan Pérez de Moya. In: CARRILLO, D. et al. (Ed.). CONGRESO IBEROAMERICANO DE HISTORIA DE LA EDUCACIÓN MATEMÁTICA, 4., 2018. Murcia. Actas ... Murcia: Centro de Estudios sobre la Memoria Educativa, 2018. p. 235 - 243.

NAVARRO, V. La revolución científica de España. Tradición y renovación en las ciencias físicomatemáticas. 1978. 2v. PhD Dissertation (History of Physics) - Universidad de Valencia, Valencia, 1978.

NAVARRO, V. La personalidad científica de Thomas Vicente Tosca (1651-1723). Boletín informativo de la fundación Juan March, Madrid, v. 37, p. 3 - 14, 1987.

NAVARRO, V. El moviment novator en les ciències fisicomatemàtiques. In: VERNET, J.; PARÉS R. (Ed.). La Ciència en la Història dels Països Catalans, vol. II. València: Institut d'Estudis Catalans i Universitat de València, 2007. p. 381 - 411.

NAVARRO LOIDI, J. Don Pedro Giannini o las matemáticas de los artilleros en el siglo XVIII. Segovia: Biblioteca de Ciencia y Artillería, 2013. 701 p.

OLLER MARCÉN, A. M.; MEAVILLA SEGUÍ, V. El primer tomo de las Cartas Físico-Matemáticas de Teodosio a Eugenio. Un curioso texto geométrico escrito en formato epistolar. Revista Brasileira de História da Matemática, Campinas, v. 13, n. 26, p. 1 - 21, 2013.

PAJARES, F. Teachers' beliefs and educational research: Cleaning up a messy construct. Review of Educational Research, London, v. 62, n. 39, p. 307 - 332, 1992.

PATIONITIS, M. Textbooks at the Crossroads: Scientific and Philosophical Textbooks in 18th Century Greek Education. Science \& Education, Dordrecht, v. 15, n. 7 - 8, p. 801 - 822, 2006.

PONTE, J.P. Mathematics teachers' professional knowledge. In: PONTE, J. P.; MATOS, J. F. (Ed.). PME, 18., 1994. Lisbon. Proceedings... Lisbon: PME, 1994. p. 195 - 210.

PRIOR L. Using documents in social research. In: SILVERMAN D. (Ed.). Qualitative research. London: SAGE, 2016. p. 171-185.

RAMPLING, J.M. The Elizabethan mathematics of everything: John Dee's 'Mathematicall praeface' to Euclid's Elements. BSHM Bulletin: Journal for the British Society for the History of Mathematics, London, v. 26, n. 3, p. 135 - 146, 2011.

RODRÍGUEZ PARDO, J.M. El alma de los brutos en el entorno del Padre Feijoo. Oviedo: Fundación Gustavo Bueno, 2008. 519 p.

ROSSELLÓ I VERGER, V.M. Tomàs V. Tosca y su entorno ilustrado en Valencia. Obra autógrafa y atribuciones. Ería. Revista Cuatrimestral de Geografía, Oviedo, v. 64 - 65, p. 159 - 176, 2004.

SCHUBRING, G. On the methodology of analysing historical textbooks: Lacroix as textbook author. For the learning of mathematics, Fredericton, v. 7, n. 3, p. 41 - 51, 1987.

SCOTT J. A matter of record, documentary sources in social research. Cambridge: Polity Press, 1990. $244 \mathrm{p}$.

SWETZ, F. To know and to teach: mathematical pedagogy from a historical context. Educational 
Studies in Mathematics, Heidelberg, v. 29, p. 73 - 88, 1995.

THOMPSON, A.G. Teachers' beliefs and conceptions: A synthesis of research. In: GROUWS D.A. (Ed.). Handbook of Research on Mathematics Teaching and Learning. New York: McMillan, 1992. p. 127 - 146.

VITRAC, B. Promenade dans les préfaces des textes mathématiques grecs anciens. In: RADELETDE-GRAVE, P. (Ed.). Liber amicorum Jean Dhombres. Turnhout: Brepols, 2008. p. 519 - 556.

Submetido em 08 de Agosto de 2018. Aprovado em 17 de Fevereiro de 2019. 